\title{
Actinomyces meyeri sp. nov., Specific Epithet rev.
}

\author{
ELIZABETH P. CATO, ${ }^{1 *}$ W. E. C. MOORE, ${ }^{1}$ GENEVIEVE NYGAARD ${ }^{2}$ AND LILLIAN V. HOLDEMAN ${ }^{1}$
}

Department of Anaerobic Microbiology, Virginia Polytechnic Institute and State University, Blacksburg, Virginia $24061,{ }^{1}$ and California State Department of Health Services, Microbial Diseases Laboratory, Berkeley, California $94704^{2}$

\begin{abstract}
We propose that "Actinobacterium meyeri" be placed in the genus Actinomyces as Actinomyces meyeri. A description of the species is presented. The proposed type strain is strain ATCC 35568 (= Prévot $2477 \mathrm{~B}=$ VPI 8617).
\end{abstract}

Actinobacterium israelii, the type species of the genus Actinobacterium Sampietro 1908, was transferred to the genus Actinomyces Harz 1877 by Breed and Conn in 1919 (2). This effectively invalidated the name Actinobacterium according to Rule 37a of the International Code of Nomenclature of Bacteria (6). The genus name Actinobacterium was not included on the Approved Lists of Bacterial Names in 1980 (13) and thus has no standing in nomenclature. In the system of classification of Prévot, the genus Actinobacterium was included as late as 1968 (1) and comprised those species of the family Actinomycetaceae that were obligately anaerobic, at least on isolation. "Actinobacterium israelii" was retained as the type species, and "Actinobacterium meyeri," which was proposed by Prévot in 1938 (10), was included in the genus. Strains with the characteristics of "Actinobacterium meyeri" (11) have been isolated frequently from brain abscesses, from pleural cavities, and from both healthy and diseased subgingival pockets of humans $(8,9$, 12). Because this organism may be a significant human pathogen, we propose the new species Actinomyces meyeri for these strains, with strain ATCC 35568 as the type strain.

The results of a study of 16 strains, 5 of which were identified by A.-R. Prévot as "Actinobacterium meyeri," are presented below. The sources of these strains are shown in Table 1. The anaerobic methods that we used are described in the Anaerobe Laboratory Manual (4). The strains were tested for fluorescent antibody staining as described by Slack and Gerencser (14) with monovalent conjugate prepared against Prévot strain 2801 (= ATCC 33972). Antibiotic susceptibilities were determined by the broth disk method of Wilkins and Thiel (15).

Actinomyces meyeri sp. nov. (basionym, "Actinobacterium meyeri" A.-R. Prévot 1938,303; mey' er.i. N.L. gen. n. meyeri named for K. F. Meyer, German bacteriologist who first isolated the species). Cells in peptone-yeast extractglucose broth cultures supplemented with vitamin $\mathrm{K}_{1}$, hemin, and Tween 80 (4) are short, gram-positive, nonsporeforming, nonmotile rods 0.5 to 0.9 by 0.9 to $3.0 \mu \mathrm{m}$ and occur in pairs, short chains, or clumps. Terminal swellings are present occasionally.

Surface colonies on supplemented brain heart infusion blood agar plates are pinpoint to $1 \mathrm{~mm}$ in diameter, circular, flat to convex, translucent to opaque, and white, with shiny, smooth surfaces and entire margins. They may be alpha- or nonhemolytic. Growth is abundant on plates incubated anaerobically; very slight growth may occur on plates incubated in air enriched with $5 \% \mathrm{CO}_{2}$; there is no growth on plates incubated aerobically.

Cultures in peptone-yeast extract-glucose broth are only slightly turbid with a smooth or stringy sediment and have a $\mathrm{pH}$ of 4.6 to 5.0 after incubation for 5 days.

\footnotetext{
* Corresponding author.
}

Strains grow equally well at 30 or $37^{\circ} \mathrm{C}$; they grow nearly as well at $25^{\circ} \mathrm{C}$ but not at all at $45^{\circ} \mathrm{C}$. They have an absolute requirement for vitamin $K_{1}$, and growth is greatly stimulated by $0.02 \%$ Tween 80 and by fermentable carbohydrate. There is no growth in $20 \%$ bile or $6.5 \% \mathrm{NaCl}$.

No gas is formed in peptone-yeast extract-glucose agar deep cultures; neither hydrogen nor $\mathrm{H}_{2} \mathrm{~S}$ is produced; ammonia may be produced in chopped meat cultures. Acid is produced from glucose, fructose, maltose, starch, sucrose, ribose, and xylose; fermentation of amygdalin, arabinose, galactose, glycogen, glycerol, and lactose is variable (Table 2); neither adonitol, dulcitol, erythritol, inositol, mannitol, sorbitol, cellobiose, esculin, inulin, mannose, melezitose, melibiose, pectin, raffinose, rhamnose, salicin, sorbose, nor trehalose is fermented. Neither indole, acetylmethylcarbinol, catalase, lecithinase, nor lipase is produced. Production of urease is variable when organisms are tested in paptoneyeast extract-urea broth (4). Proline deaminase and $\alpha$-glucosidase are produced when organisms are tested by the APIZYM system (Analytab Products, Plainview, N.Y.). Milk is curdled by those strains that ferment lactose. Esculin, starch, and hippurate are not hydrolyzed. Nitrate is not reduced; neutral red is reduced, but the reduction of resazurin is variable. There is no digestion of gelatin or chopped meat.

The products of fermentation in peptone-yeast extractglucose broth are formic, acetic, and succinic acids, with small amounts of lactic or pyruvic acid occasionally detected. Neither lactate, threonine, nor gluconate is utilized; pyruvate is converted to formate and acetate.

TABLE 1. Sources of strains of Actinomyces meyeri

\begin{tabular}{ll}
\hline $\begin{array}{l}\text { VPI } \\
\text { number }\end{array}$ & \multicolumn{1}{c}{ Source } \\
\hline 8617 & purulent pleurisy, Prévot 2477B, ATCC 35568, type strain \\
8611 & cervico-facial actinomycosis, Prévot 3732 \\
$8620 B$ & brain abscess, Prévot 2169 \\
8622 & purulent meningitis, Prévot 2463 \\
10648 & unknown, Prévot 2801, antigen strain, ATCC 33972 \\
10757 & chest wall, Maryland \\
11313 & brain abscess, Massachusetts \\
11346 & facial actinomycosis, Delaware \\
11706 & brain abscess, Texas \\
$11857 B$ & bartholin cyst, Tennessee \\
$11858 A$ & subdural abscess, Tennessee \\
11983 & mandible, Texas \\
12065 & empyema, Delaware \\
12313 & thoracentesis fluid, California \\
D27F26 & subgingival-crevice, severe periodontitis, Virginia \\
D39B11 & subgingival crevice, healthy, Virginia \\
\hline
\end{tabular}


TABLE 2. Variable reactions of strains of Actinomyces meyeri

\begin{tabular}{lcc}
\hline & $\begin{array}{c}\text { ATCC } \\
35568 \\
\text { type strain }\end{array}$ & $\begin{array}{c}\text { reaction } \\
\text { positive } \\
\text { (no. of strains) }\end{array}$ \\
\hline Acid from & & \\
Amygdalin & + & $20(50)$ \\
Arabinose & - & $19(50)$ \\
Galactose & - & $9(15)$ \\
Glycerol & - & $16(33)$ \\
Glycogen & + & $24(50)$ \\
Lactose & + & $22(50)$ \\
Milk curded & + & $37(50)$ \\
Urease produced & + & $10(16)$ \\
\hline
\end{tabular}

The patterns of soluble cellular proteins as determined by polyacrylamide gel electrophoresis (7) illustrate the homogeneity of the strains examined (Fig. 1).

In a numerical taxonomic study, Holmberg and Nord (5) reported that four of these strains form a cluster related to but distinct from other species in the genus Actinomyces.

All of the strains listed in Table 1 give a positive fluorescent antibody reaction with a monovalent conjugate prepared against strain ATCC 33972. No cross-reactions have been found with conjugates to other species of oral isolates, including two serotypes of Actinomyces israelii, two serotypes of Actinomyces odontolyticus, three serotypes of Actinomyces naeslundii, Actinomyces viscosus, and a common but unnamed oral isolate, Actinomyces sp. strain WVU 963. Several strains that are otherwise phenotypically identi-

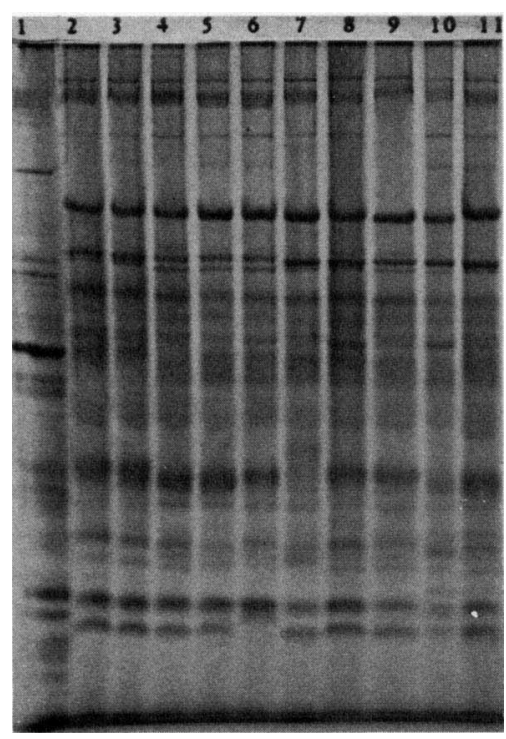

FIG. 1. PAGE protein patterns of strains of A. meyeri. Lane 1. Streptococcus faecalis U4-20, reference strain; lanes 2-11, Actinomyces meyeri: $2=$ ATCC 33972 (antigen strain); $3=8611 ; 4=$ ATCC 35568 (type strain); $5=8620 \mathrm{~B} ; 6=8622 ; 7=11346 ; 8=$ $12065 ; 9=\mathrm{D} 39 \mathrm{~B} 11 ; 10=\mathrm{D} 27 \mathrm{~F} 26 ; 11=10757$. cal to Actinomyces meyeri do not react with this conjugate although their protein patterns are similar, which indicates that there are other serotypes of the species.

All of the strains tested are susceptible to achievable blood levels of chloramphenicol, clindamycin, erythromycin, penicillin $\mathrm{G}$, and tetracycline.

Actinomyces meyeri can be distinguished from Actinomyces israelii and Actinomyces naeslundii by not fermenting raffinose, from Actinomyces viscosus by not producing catalase, from Actinomyces odontolyticus by not producing pink colonies on blood agar and by not reducing nitrate, from Actinomyces bovis by fermenting ribose and xylose, and from Actinomyces sp. strain WVU 963 by not hydrolyzing esculin.

The principal habitat of Actinomyces meyeri is human periodontal sulci. It has been isolated frequently from brain abscesses and pleural fluid and less often from abscesses of hips, hands, feet, and spleens and from bite wounds.

The type strain of Actinomyces meyeri is strain ATCC 35568 (= Prévot 2477B = VPI 8617). The guanine-pluscytosine content of this strain, as determined by chromatographic analysis, is $67 \mathrm{~mol} \%$ (1).

We thank Pauletta C. Atkins, Leesa R. Miller, Sue C. Smith, Luba S. Fabrycky, Ann C. Ridpath, and Linda L. Long for bacteriological analyses; Debra B. Sinsabaugh for serological studies; Donald E. Hash for electrophoretic analyses; and Donya B. Stephens and Mary P. Harvey for typing assistance.

This work was supported by Public Health Service grants DE05054 and DE-05139 from the National Institute of Dental Research and by project 2022820 from the Commonwealth of Virginia.

\section{LITERATURE CITED}

1. Bouisset, L., J. Brouillard, G. Michel, and G. Larrouy. 1968. Bases nucléiques des bactéries. Application au genre Actinobacterium. Ann. Inst. Pasteur Paris 115:1063-1081.

2. Breed, R. S., and H. J. Conn. 1919. The nomenclature of the Actinomycetaceae. J. Bacteriol. 4:585-602.

3. Buchanan, R. E., J. G. Holt, and E. F. Lessel, Jr. (ed.). 1966. Index bergeyana. The Williams \& Wilkins Co. Baltimore.

4. Holdeman, L. V., E. P. Cato, and W. E. C. Moore (ed.). 1977. Anaerobe laboratory manual, 4th ed. Virginia Polytechnic Institute and State University, Blacksburg.

5. Holmberg, K., and C.-E. Nord. 1975. Numerical taxonomy and laboratory identification of Actinomyces and Arachnia and some related bacteria. J. Gen. Microbiol. 91:17-44.

6. Lapage, S. P., P. H. A. Sneath, E. F. Lessel, V. B. D. Skerman, H. P. R. Seeliger, and W. A. Clark (ed.). 1975. International code of nomenclature of bacteria. 1975 Revision. American Society for Microbiology, Washington, D.C.

7. Moore, W. E. C., D. E. Hash, L. V. Holdeman, and E. P. Cato. 1980. Polyacrylamide slab gel electrophoresis of soluble proteins for studies of bacterial floras. Appl. Environ. Microbiol. 39:900-907.

8. Moore, W. E. C., L. V. Holdeman, R. M. Smibert, D. E. Hash, J. A. Burmeister, and R. R. Ranney. 1982. Bacteriology of severe periodontitis in young adult humans. Infect. Immun. 38:1137-1148.

9. Moore, W. E. C., R. R. Ranney, and L. V. Holdeman. 1982. Subgingival microflora in periodontal disease: cultural studies, p. 13-26. In R. J. Genco and S. E. Mergenhagen (ed.), Hostparasite infections in periodontal diseases. American Society for Microbiology, Washington, D.C.

10. Prévot, A.-R. 1938. Études de systématique bactérienne. Ann. Inst. Pasteur Paris 60:285-307.

11. Prévot, A.-R. 1966. Manual for the classification and determination of the anaerobic bacteria. Translated by V. Fredette. Lea \& Febiger, Philadelphia.

12. Schaal, K. P., and G. Pulverer. 1981. The genera Actinomyces, Agromyces, Arachnia, Bacterionema, and Rothia, p. 1923- 
1950. In M. P. Starr, H. Stolp, H. G. Trüper, A. Balows, and H. G. Schlegel (ed.), The prokaryotes, vol. 2. Springer-Verlag, New York.

13. Skerman, V. B. D., V. McGowan, and P. H. A. Sneath (ed.). 1980. Approved lists of bacterial names. Int. J. Syst. Bacteriol. 30:225-420.
14. Slack, J. M., and M. A. Gereneser. 1975. Actinomyces, filamentous bacteria: biology and pathogenicity. Burgess Publishing Co., Minneapolis.

15. Wilkins, T. D., and T. Thiel. 1973. A modified broth-disk method for testing the antibiotic susceptibility of anaerobic bacteria. Antimicrob. Agents Chemother. 3:350-356. 